\title{
Digestibility of diets with flour fish silage for the growing of arawana (Osteoglossum bicirrhossum)
}

\author{
Digestibilidad de dietas con harina de hidrolizado de pescado, para \\ el levante de arawana (Osteoglossum bicirrhossum)
}

\author{
Mario Paz A, ${ }^{1}$ Ing, John Meneses $\mathrm{R},{ }^{1}$ Ing, Jorge López M, ${ }^{1 *}$ Ph.D.
}

1 Universidad de Nariño, Faculty of Fish Sciences, Department of Hydrobiological Resources, Calle $18 \mathrm{Cr}$. 50. Ciudad Universitaria Torobajo, San Juan de Pasto, Colombia. *Correspondence: jorgelopezmacias@ gmail.com

Received: May 2014; Accepted: June 2015.

\begin{abstract}
Objective. The purpose of this research was to evaluate the digestibility of different nutritional and energy components of artificial diets containing flour fishsilage used in growing of arawana fingerlings (O. bicirrhossum). Materials and methods. 240 fingerlings distributed in 12 tanks with 20 fish per experimental unit were handled, in a completely randomized design made up of 4 treatments with three replicates, each with inclusions of $0(0 \mathrm{ESH}), 10(10 \mathrm{ESH}), 20(20 \mathrm{ESH})$ and $30 \%$ flour fish silage (30ESH) of treatments T0, T1, T2 and T3 respectively; fromflour fish silagein order to formulate isoenergetic and isonitrogenous diets in the different treatments to avoid sources of miscalculation of the experimental variables. Results. High digestibility coefficients were observed in treatments T1 (10ESH) and T3 (30ESH). The protein, lipid and energy utilization ratios were greater than $60 \%$, which shows the importance of including flour fish silage as a source of protein to improve the various growth parameters. Significant differences between treatments were found in the increase of length $(p \leq 0.05)$, showing that the T1 was the best treatment with an average of $1.21 \pm 0.29 \mathrm{~cm}$. Conclusions. According to the coefficients of digestibility, length increase and benefit - cost ratio, the best treatment was T1 (10ESH) used to feed arawana (O. bicirrhossum), during the growing period, demonstrating the economic and ecological advantages for utilization of this source of protein in aquaculture.
\end{abstract}

Key words: Aquaculture, diets, fish silage, nutrition, protein, silver arawana (Sources: MeSH, FAO).

\section{RESUMEN}

Objetivo. Analizar la digestibilidad de los diferentes componentes nutricionales y energéticos en dietas balanceadas con niveles de harina de hidrolizado de vísceras de cachama en el alevinaje de arawana (O. bicirrhossum). Materiales y métodos. Se evaluaron 240 alevinos, distribuidos en 12 acuarios a razón de 1 animal/5 L. Se utilizó un diseño completamente al azar, conformado por cuatro tratamientos con tres réplicas cada uno, con inclusiones de $0(0 \mathrm{ESH}), 10(10 \mathrm{ESH}), 20(20 \mathrm{ESH})$ y $30 \%$ de extracto seco de hidrolizado de vísceras de cachama (30ESH) para los tratamientos T0, T1, T2 y T3 respectivamente; para evitar fuentes de error en el cálculo de las variables experimentales, se formularon dietas isoenergéticas e isonitrogenadas. Resultados. Se detectaron diferencias estadísticas significativas en el incremento de longitud $(p \leq 0.05)$, indicando que el T1 (10ESH) es el mejor tratamiento con un promedio de talla de $1.21 \pm 0.29 \mathrm{~cm}$, además, se obtuvieron coeficientes 
de digestibilidad superiores al $60 \%$ en los tratamientos T1 (10ESH) y T3 (30ESH) en lo referente a proteína, lípidos y Coeficientes de Utilización Energética (CUE); demostrando la importancia de incluir el extracto seco de hidrolizado de vísceras de cachama, en las dietas de los peces para mejorar las distintas variables zootécnicas, teniendo en cuenta la importancia acuariofílica de la especie. Conclusiones. De acuerdo con los coeficientes de digestibilidad, incrementos de longitud y la relación beneficio - costo el mejor tratamiento fue el T1 (10 ESH) en dietas de levante para O. bicirrhossum; demostrando las ventajas económicas y ecológicas de la incorporación de esta materia prima en la alimentación acuícola.

Palabras Clave: Acuacultura, arawana plateada, dietas, ensilado, nutrición, proteína. (Fuentes: DeCS, FAO).

\section{INTRODUCTION}

The silver arawana (O. bicirrhossum) is a fish species that inhabits the Amazon River and its tributaries: Putumayo, Caquetá and Orinoco (1). It is characterized as having high commercial value in cultivation destined for human consumption and sport fishing due to their shape and color that make them appealing and attractive to the fish market. This has resulted in the species being listed in the Red Book for freshwater fish, considered endangered (2).

Most aquaculture feeding trials have been conducted without establishing digestibility coefficients for the diets, which means that the nutritional benefits of one material in comparison with others cannot really be determined. For this reason, one of the most important aspects in assessing the effectiveness of feed is understanding the rate of assimilation that quantifies the ability of the fish to digest and absorb nutrients from its diet. This is essential to formulate practical fish feed diets based on determining nutritional requirements, which in turn are related to the content of digestible nutrients. A diet's digestibility depends on the age of the animal, its physiology, the physicchemical and biological characteristics of water, the nutritional value of different types of raw materials and how the nutrients interact. In aquaculture production, $15 \%$ of the weight comes from viscera, which is removed and poured directly into water sources, thus creating pollution and spreading pathogens to captive and natural fish populations (3).

Techniques to properly dispose of offal that would increase rates of return should be evaluated and implemented to maintain the physicochemical and bacteriological quality of bodies of water and their use in manufacturing balanced diets for fish. Therefore, this study determined the digestibility coefficients to establish the quality of raw materials used in aquaculture production by using dry hydrolyzed cachama viscera in varying percentages and measuring its effect on

\section{INTRODUCCIÓN}

La arawana plateada (O. bicirrhosum) es una especie íctica que habita en el río Amazonas y sus tributarios Putumayo, Caquetá y Orinoco (1), se caracteriza por poseer un alto valor comercial en cultivos destinados a consumo humano, pesca deportiva y debido a sus condiciones de forma y color que lo hacen llamativo y atractivo para el mercado acuarista, ha ocasionado que la especie se encuentre catalogada en el libro rojo de peces de agua dulce como especie en peligro (2).

La mayoría de los ensayos de alimentación acuícola, se han realizado sin establecer los coeficientes de digestibilidad de las dietas; lo cual no permite determinar realmente las ventajas nutricionales de una materia prima en comparación con otras. Por esta razón, uno de los aspectos más importantes en la evaluación de la efectividad de un insumo alimenticio es el conocimiento de la tasa de asimilación, que cuantifica la habilidad del pez para digerir y absorber los nutrientes de la dieta que ingiere. Lo anterior es fundamental para la formulación de dietas prácticas para peces, basadas en la determinación de los requerimientos nutricionales, que a la vez están relacionados con el contenido de nutrientes digestibles. La digestibilidad de una dieta depende de la edad del animal, fisiología, características fisicoquímicas y bacteriológicas del agua, valor nutricional de los distintos tipos de materias primas e interacción de nutrientes. En una producción acuícola, el 15\% del peso lo representan las vísceras, las cuales son eliminadas de las explotaciones; vertiéndolas directamente a las fuentes de agua; generando problemas de contaminación y propiciando la propagación de patógenos a las poblaciones de peces en cautiverio y naturales (3).

La evaluación de técnicas que permitan la disposición correcta de las vísceras e incremento de las tasas de rentabilidad; deben implementarse por su impacto positivo en el mantenimiento de la calidad fisicoquímica, bacteriológica de los cuerpos de agua y la utilización de estos 
the zootechnical parameters of simple growth rate, survival, feed conversion and increased size during the cultivation of silver arawana.

\section{MATERIALS AND METHODS}

Study site and installations. Field work was conducted on the "VAI" fish station of the Aquaculture Association of Caquetá (ACUICA), which is located in El Quebradón in the northeastern department of Caquetá, on the road to El Doncello, 65 kilometers from Florencia, at the following geo coordinates: $1^{\circ} 40^{\prime}$ $46^{\prime \prime}$ North and $75^{\circ} 16^{\prime} 45^{\prime \prime}$ West, at 373 meters above sea level, average temperature $26^{\circ} \mathrm{C}$ and an average rainfall of $3200 \mathrm{~mm} /$ year in normal conditions (4). The evaluation was carried out in a greenhouse type system in which 12 100-liter aquariums were placed $(90 \mathrm{~cm}$ long by $30 \mathrm{~cm}$ wide and $40 \mathrm{~cm}$ high). Each unit was equipped with a thermostat, ventilation system and filter to provide the appropriate conditions for the fish species studied.

Biological material and management. 500 silver Arawana were initially obtained with an average weight of $1.2 \pm 0.2 \mathrm{~g}$., vitelinic larvae. The fish were transferred to the greenhouse where they were randomized into aquariums for a period of four months, three of which were devoted to cultivation and feed and one for study purposes.

The aquariums were kept at an average temperature of $30.2 \pm 1.6^{\circ} \mathrm{C}$. The acclimation period lasted two weeks, during which labors such as siphoning, $90 \%$ daily water exchange, and recording of physicochemical parameters such as temperature and oxygen was done with a YSI 550A probe and $\mathrm{pH}$ with Hach equipment to keep the fish in optimal condition. After the yolk sac was absorbed, the fish were fed with commercial flakes with $48 \%$ protein for a month, which was gradually replaced with an extruded commercial diet of $45 \%$ ( $p / v)$ protein, supplied three times a day until the population reached an average standard length of $9.8 \pm 0.9 \mathrm{~cm}$. and an average weight of $6.6 \pm 2.5 \mathrm{~g}$. These values showed no statistical difference $(p>0.05)$. Later, evaluation of experimental diets was initiated with 240 fish, establishing inclusions at 0 (OESH), 10 (10ESH), 20 (20ESH) and 30\% dry hydrolyzed cachama viscera (Piaractus brachypomus) (30ESH) for T0, T1, T2 and T3 treatments respectively, with 20 animals per experimental unit and a daily supply of biomass at $6 \%$, distributed in five meals a day.

Raw materials for the diet. The nutritional needs of native fish species grown in captivity can subproductos en la fabricación de dietas balanceadas para peces. Por lo anteriormente expuesto, la presente investigación determina los coeficientes de digestibilidad, para establecer la calidad de las materias primas utilizadas en la producción acuícola; a partir de extracto seco de hidrolizado de vísceras de cachama en diferentes porcentajes y el efecto sobre los parámetros zootécnicos de tasa de crecimiento simple, sobrevivencia, conversión alimenticia e incremento de talla durante la fase de levante de arawana plateada.

\section{MATERIALES Y MÉTODOS}

Sitio de estudio e instalaciones. El trabajo de campo se realizó en la estación piscícola "VAI" perteneciente a la Asociación de Acuicultores del Caquetá (ACUICA), la cual se encuentra ubicada en la Vereda El Quebradón en el noreste del departamento del Caquetá, en la vía al municipio de El Doncello a una distancia de 65 kilómetros de Florencia con coordenadas geográficas de $1^{\circ} 40^{\prime} 46^{\prime \prime}$ latitud Norte y $75^{\circ} 16^{\prime} 45^{\prime \prime}$ longitud Oeste, a 373 m.s.n.m., temperatura promedio ambiente de $26^{\circ} \mathrm{C}$ y una pluviosidad promedio de $3200 \mathrm{~mm} /$ año en condiciones normales (4). La evaluación se llevó a cabo en un sistema tipo invernadero, en el cual se instalaron 12 acuarios de 100 litros $(90 \mathrm{~cm}$ de largo por $30 \mathrm{~cm}$ de ancho y $40 \mathrm{~cm}$ de alto). Cada unidad fue dotada de un termostato, sistema de aireación y un filtro, para brindar las condiciones apropiadas para la especie íctica objeto de estudio.

Material biológico y manejo. Se obtuvieron inicialmente 500 ejemplares de arawana plateada con un peso promedio de $1.2 \pm 0.2$ g., los cuales se encontraban en estado de larva vitelínica. Los peces fueron trasladados al sistema tipo invernadero, donde fueron distribuidos aleatoriamente en acuarios por un período de cuatro meses, tres de los cuales se dedicaron al levante y adaptación alimentaria y uno al desarrollo de la investigación.

Los acuarios fueron acondicionados a una temperatura promedio de $30.2 \pm 1.6^{\circ} \mathrm{C}$. El período de aclimatación de los individuos duró dos semanas, durante las cuales se efectuaron labores de sifoneo, recambio de agua del $90 \%$ diario y registro de parámetros fisicoquímicos como temperatura y oxígeno con una sonda YSI $550 \mathrm{~A}$ y $\mathrm{pH}$ con un equipo Hach, para mantener los animales en óptimas condiciones. Después de la reabsorción del saco vitelino, los ejemplares se adaptaron a balanceado comercial en hojuelas con $48 \%$ de proteína durante un mes, el cual fue remplazado gradualmente con una dieta comercial extrudizada de $45 \%$ ( $p / v)$ de proteína, 
be met by providing artificial feed prepared with raw materials that have appropriate digestibility and palatability and that also meet the minimum nutritional requirements for the species under cultivation (3). To formulate the diets meat meal, soybean (Glycine max), fish, corn (Zea mays), wheat bran and bean flour (Phaseolus spp.) was used. Since one of the most expensive raw materials is fishmeal, this study proposed partially replacing this protein with hydrolyzed cachama viscera.

Preparing the hydrolyzed product and flour. The process took place in the laboratories of the Universidad de Nariño using $50 \mathrm{~kg}$ of cachama viscera which had the fat tissue and gastrointestinal contents removed. This raw material was ground to a homogeneous visceral paste and molasses, plain yogurt and potassium sorbate (Sigma-Aldrich, St. Louis, MO) were added in amounts of 15,3 and $0.2 \%$ respectively (5). This was stored in glass and plastic containers for a ripening time of 216 hours during which it reached a $\mathrm{pH}$ of $4.10 \pm 0.07$, optimal for inhibiting the growth of pathogens that could affect the product (6). This process was done in an incubator (Memmert, Schwabach, Germany) at a temperature of $38 \pm 2{ }^{\circ} \mathrm{C}$.

The ripe hydrolyzed product was transferred to a Styrofoam cooler to keep it isolated from moisture and sunlight, maintaining the $\mathrm{pH}$ range specified above. The average amount per container did not exceed $60 \%$ of the total volume to leave room for gas production due to fermentation; once hydrolysis was established and $\mathrm{pH}$ stability achieved, the flour was made by drying the mixture; the hydrolyzed product was poured into stainless steel trays in $4 \mathrm{~mm}$ layers and was dried at a temperature of $60^{\circ} \mathrm{C}$ in an oven (Memmert, Schwabach, Germany) for 14 hours to obtain a hard paste, and then was put through a micro mill (IKA, Staufen, Germany) to produce flour.

Bromatologic analysis of ingredients, preparation and balancing the diets. Each selected raw material was milled and sieved to a particle size of 450 microns to facilitate homogenization, and a proximal and energy analysis was performed following the Weende methodology as applied by specialized laboratories at the University of Nariño (Table 1). Isonitrogenous and isocaloric diets were obtained using the commercial program Feedsoft Enterprise (2010) and the Excel Solver (2010) tool using protein levels of not less than $45 \%$ and energy that did not exceed $5270 \mathrm{Kcal} / \mathrm{kg}$, as well as the limited use of some ingredients according to sales costs, digestibility and what is recommended by Vazquez (7). suministrada tres veces al día hasta que la población alcanzó una longitud estándar promedio de $9.8 \pm 0.9 \mathrm{~cm}$. y peso promedio de $6.6 \pm 2.5 \mathrm{~g}$. Los anteriores valores no registraron diferencias estadísticas $(p>0.05)$. Posteriormente se inició la evaluación de las dietas experimentales con 240 animales, estableciendo inclusiones de $0(\mathrm{OESH}), 10(10 \mathrm{ESH}), 20(20 \mathrm{ESH})$ y $30 \%$ de extracto seco de hidrolizado de vísceras de cachama blanca (Piaractus brachypomus) (30ESH) para los tratamientos T0, T1, T2 y T3 respectivamente, con 20 animales por unidad experimental y suministro diario del $6 \%$ de la biomasa, distribuido en cinco comidas al día.

Materias primas de las dietas. Las necesidades nutricionales de las especies ícticas nativas, cultivadas en cautiverio, pueden ser cubiertas mediante el suministro de balanceados artificiales preparados con materias primas de digestibilidad y palatabilidad adecuadas que además, cumplan con los requerimientos nutricionales mínimos de la especie objeto de cultivo (3). En la formulación de las dietas se incorporó harinas de carne, soya (Glycine max), pescado, maíz (Zea mays), afrecho de trigo (wheat bran) y harina de frijol (Phaseolus spp.). Considerando que una de las materias primas más costosas es la harina de pescado, el presente ensayo propuso el remplazo parcial de este ingrediente proteico por harina de hidrolizado de vísceras de cachama.

Elaboración del hidrolizado y preparación de la harina. El proceso se realizó en los Laboratorios de la Universidad de Nariño, a partir de $50 \mathrm{~kg}$ de vísceras de cachama, a los cuales se les retiró el tejido graso y el contenido gastrointestinal, luego esta materia prima se molió hasta obtener una pasta visceral homogénea, se adicionó melaza, yogurt sin sabor y sorbato de potasio (Sigmaaldrich, St. Louis, MO) en cantidades de 15, 3 y $0.2 \%$ respectivamente (5). La preparación se almacenó en recipientes plásticos y de cristal, durante un tiempo de maduración de 216 horas, período en el cual se alcanzó un $\mathrm{pH}$ de $4.10 \pm 0.07$, óptimo para la inhibición del crecimiento de patógenos que podían afectar el producto (6), este proceso se llevó a cabo en una incubadora (Memmert, Schwabach, Germany) a temperatura de $38 \pm 2^{\circ} \mathrm{C}$.

El hidrolizado maduro, se transfirió a una nevera de icopor para mantenerlo aislado de humedad y luz solar, conservando el rango de $\mathrm{pH}$ anteriormente indicado. La cantidad promedio calculada por recipiente no superó el $60 \%$ del volumen total, dejando espacio para la producción de gas como producto de la fermentación; una vez establecida la hidrólisis y alcanzada la estabilidad del $\mathrm{pH}$, se formó su harina a través de un proceso de secado. Para 
Table 1. Approximate analysis (\%) and gross energy of the ingredients in different diets prepared with the dry hydrolyzed extract of cachama viscera.

\begin{tabular}{lcccc}
\hline \multicolumn{1}{c}{ Raw material } & $\begin{array}{c}\text { Protein } \\
(\%) *\end{array}$ & $\begin{array}{c}\text { Ether } \\
\text { extract } \\
(\%)\end{array}$ & $\begin{array}{c}\text { Raw } \\
\text { fiber } \\
(\%)\end{array}$ & $\begin{array}{c}\text { Energy } \\
\text { (Kcal/100g) }\end{array}$ \\
\hline Meat flour & 63.2 & 24.8 & 0 & 623 \\
Soy flour & 49.7 & 0.88 & 4.96 & 465 \\
Fish flour & 52.5 & 12.7 & 0 & 525 \\
dry hydrolyzed extract & 37.7 & 26.3 & ---- & 577 \\
of cachama viscera & & 4.62 & 2.03 & 442 \\
Ground corn & 8.25 & 1.45 & 8.87 & 403 \\
Roasted bean flour & 24.0 & 4.73 & 7.72 & 461 \\
Wheat bran & 17.4 & 4.73 &
\end{tabular}

*Percentage in dry base. Specialized laboratory, Universidad de Nariño, 2010.

Each diet was supplemented with $0.3 \%$ commercial mineral and vitamin premix for fish (DSM Nutritional Products, Bogotá, Colombia); Fish oil was also added at $3 \%$ carboxymethyl cellulose (CMC) at $1 \%$ to provide fiber and a binder and as a digestibility marker chromic oxide (Cr2O3) (Carlo Erba, Sabadell, Barcelona) at $0.9 \%$.

To develop treatments they first weighed and mixed the flour and then the micro-ingredients until the greatest possible homogenization was achieved. Each treatment was moistened with $25 \%$ water and then the mixture was passed through a sieve with one millimeter mesh. The extruding process was done at the Laboratory of Aquatic Nutrition, Unit for Food Processing at the National Universidad de Colombia using a laboratory micro-extruder (Exteec, Vila, Brazil) to obtain $5 \mathrm{~mm}$ granules that were then allowed to dry for 24 hours at $60^{\circ} \mathrm{C}$ and the fish oil was immediately added using a spray method.

Sample collection and analysis. They were collected five times daily; two in the morning and three in the afternoon in order to prevent leaching of fecal matter; during feeding and siphoning of the aquarium aeration was discontinued. Then they were stored in previously labeled plastic containers at an average temperature of $-10^{\circ} \mathrm{C}$. Feces were collected per aquarium to remove pollutants and were stored for treatment. The collection period lasted for 30 days until $50 \mathrm{~g}$ of sample treatment was collected.

Proximate analysis of food and feces was made following the Weende methodology. Likewise, the amount of chromic oxide present in diets and feces was determined according to the Furukawa method (1993) adapted by the specialized laboratory at the University of Nariño, which involves adding $5 \mathrm{ml}$ of concentrated nitric acid to $0.1 \mathrm{~g}$ of dry sample to digest for 45 minutes at $105^{\circ} \mathrm{C}$, allowing it to cool and adding $0.5 \mathrm{ml}$ of perchloric acid and then heating it to $220^{\circ} \mathrm{C}$ esto, se vertió el hidrolizado en bandejas de acero inoxidable hasta formar una capa de $4 \mathrm{~mm}$ de espesor, secando a una temperatura de $60^{\circ} \mathrm{C}$ en un horno (Memmert, Schwabach, Germany) por un tiempo de 14 horas hasta obtener una pasta dura, finalmente se llevó a un micro molino (IKA, Staufen, Germany) para obtener la harina.

Análisis bromatológico de ingredientes, preparación y balanceo de las dietas. Cada una de las materias primas seleccionadas fue molida y tamizada a un tamaño de partícula de 450 micras para facilitar la homogenización, se le realizó un análisis proximal y energético, siguiendo la metodología de Weende aplicado por los laboratorios Especializados de la Universidad de Nariño (Tabla 1). Se obtuvieron dietas isonitrogenadas e isoenergéticas, mediante el programa comercial FeedSoft Enterprise (2010) y la herramienta Solver de Excel (2010), utilizando las restricciones de nivel de proteína no menor al $45 \%$ y energía no superior a $5270 \mathrm{Kcal} / \mathrm{kg}$, e inclusiones limitadas de algunos ingredientes, según los costos de venta, digestibilidad y lo recomendado por Vázquez (7).

Cada una de las dietas fue suplementada con $0.3 \%$ de premezcla vitamínica y mineral comercial para peces (DSM Nutritional Products, Bogotá, Colombia); además se agregó aceite de pescado al 3\%, carboximetílcelulosa (CMC) al $1 \%$ como aporte de fibra y aglutinante y como marcador de digestibilidad Oxido Crómico $\left(\mathrm{Cr}_{2} \mathrm{O}_{3}\right)$ (Carlo Erba, Sabadell, Barcelona) al 0.9\%.

En la elaboración de los tratamientos se pesaron y mezclaron primero las harinas y luego los micro-ingredientes hasta lograr la mayor homogenización posible. Se humedeció cada tratamiento con un porcentaje de $25 \%$ de agua y luego se pasó la mezcla por un tamiz con ojo de malla de un milímetro. El proceso de extrudización se efectuó en el Laboratorio de Nutrición Acuícola, Unidad de Procesamiento de Alimentos de la Universidad Nacional de Colombia, con ayuda de una microextrusora (Exteec, Vila, Brasil) para laboratorio obteniendo gránulos de $5 \mathrm{~mm}$, luego se dejó secar por 24 hora a una temperatura de $60^{\circ} \mathrm{C}$ e inmediatamente se añadió el aceite de pescado por medio de un atomizador.

Colección de muestras y análisis. Se recolectaron cinco veces al día; dos en la mañana y tres en la tarde, con el fin de evitar la lixiviación de la materia fecal; durante la alimentación y sifoneo de los acuarios se suspendió la aireación. Luego se procedió a almacenarlas en recipientes plásticos previamente rotulados, a una temperatura promedio de $-10^{\circ} \mathrm{C}$. Las heces se recolectaron por acuario para facilitar la 
until chromium oxidation is seen in a change in color from green to orange; absorbance is then read at $350 \mathrm{~nm}$.

An economic analysis was done taking into account the fixed and variable costs of different experimental diets, searching for an alternative feed formula using cachama viscera produced by applying biological silage techniques to include it in the diet of silver arawana. The cost of arawana alevin were considered as well as the cost of raw materials, supplies and labor.

Experiment design. A completely random design (DCA) was used that consists of four treatments and three replicates per treatment, 20 per experimental unit for a total of 240 fish. Statistical assumptions were made to determine outliers, normality test (Chi-Square, ShapiroWilk) and homogeneity of variances (Bartlett, Levene). In the variance analysis (ANOVA) with variables that showed statistically significant differences $(p<0.05)$ the Multiple Comparison Tukey test was applied in order to establish the best treatment. Regarding the results of digestibility, the values obtained for each treatment were determined keeping in mind that no statistical analysis was performed because the feces in different replicas were homogenized. Digestibility was calculated according to the following formulas: (8).

\section{Digestibility variables}

Total digestibility coefficient:

DT $=100-100 *\left[\% \mathrm{Cr}_{2} \mathrm{O}_{3} \mathrm{AL} / \% \mathrm{Cr}_{2} \mathrm{O}_{3} \mathrm{H}\right]$, Where:

$\% \mathrm{Cr}_{2} \mathrm{O}_{3}$ AL: amount of $\mathrm{Cr}_{2} \mathrm{O}_{3}$ in feed

$\% \mathrm{Cr}_{2} \mathrm{O}_{3} \mathrm{H}$ : amount of $\mathrm{Cr}_{2} \mathrm{O}_{3}$ in feces

\section{Digestibility coefficient.}

$C D=100-\left[\left(\% \mathrm{Cr}_{2} \mathrm{O}_{3} \mathrm{AL} / \% \mathrm{Cr}_{2} \mathrm{O}_{3} \mathrm{H}\right) *\right.$ $(\% \mathrm{NH} / \% \mathrm{NAL}) * 100]$,

Where:

$\% \mathrm{Cr}_{2} \mathrm{O}_{3}$ AL: amount of $\mathrm{Cr}_{2} \mathrm{O}_{3}$ in feed

$\% \mathrm{Cr}_{2} \mathrm{O}_{3} \mathrm{H}$ : amount of $\mathrm{Cr}_{2} \mathrm{O}_{3}$ in feces

$\% \mathrm{NH}$ : amount of nutrients in feces

$\%$ NAL: amount of nutrients in feed

\section{Energy use coefficient.}

CUE $=100-\left[\left(\% \mathrm{Cr}_{2} \mathrm{O}_{3} \mathrm{AL} / \% \mathrm{Cr}_{2} \mathrm{O}_{3} \mathrm{H}\right) *\right.$

Where:

$$
(\% \mathrm{EBH} / \% \mathrm{EBA}) * 100] \text {, }
$$

$\% \mathrm{Cr}_{2} \mathrm{O}_{3}$ AL: amount of $\mathrm{Cr}_{2} \mathrm{O}_{3}$ in feed

$\% \mathrm{Cr}_{2} \mathrm{O}_{3} \mathrm{H}$ : amount of $\mathrm{Cr}_{2} \mathrm{O}_{3}$ in feces

$\% \mathrm{EBH}$ : brute energy in feces

\%EBA: brute energy in feed

Digestible energy.

$\mathrm{ED}=[\mathrm{CUE} * \mathrm{EBA}) / 100]$, eliminación de agentes contaminantes y fueron almacenadas por tratamiento. El período de recolección duró aproximadamente 30 días, hasta obtener $50 \mathrm{~g}$ de muestra por tratamiento.

Se efectuó el análisis proximal del alimento y las heces siguiendo la metodología de Weende. Igualmente, se determinó la cantidad de óxido crómico presente en las dietas y heces de acuerdo al método de Furakawa (1993) adaptado por los laboratorio especializados de la Universidad de Nariño el cual consiste en añadir $5 \mathrm{ml}$ de ácido nítrico concentrado a una muestra seca de $0.1 \mathrm{~g}$ para llevar a digestión por 45 minutos a $105^{\circ} \mathrm{C}$, se deja enfriar y se adiciona $0.5 \mathrm{ml}$ de ácido perclórico, luego se calienta a $220^{\circ} \mathrm{C}$ hasta la oxidación del cromo proceso que se evidencia con el cambio de color de verde a naranja; posteriormente se lee absorbancia a $350 \mathrm{~nm}$.

Se efectuó un análisis económico teniendo en cuenta los costos fijos y variables de las diferentes dietas experimentales, buscando como alternativa la formulación de un alimento propio generado a partir de vísceras de cachama, aplicando técnicas de ensilaje biológico, para la inclusión de la dieta en la producción de arawana plateada. Para este efecto se consideraron los costos de los alevinos de arawana, el valor de las materias primas utilizadas, insumos y mano de obra en la producción.

Diseño experimental. Se utilizó un diseño completamente al azar (DCA) conformado por cuatro tratamientos y tres réplicas por tratamiento, 20 ejemplares por unidad experimental para un total de 240 peces. Se realizaron los supuestos estadísticos para determinar datos atípicos, prueba de normalidad (Chi-Cuadrado, ShapiroWilk) y homogeneidad de varianzas (Bartlett, Levene); en el análisis de varianza (ANAVA) con las variables que presentaron diferencias estadísticas significativas $(p<0.05)$, se procedió a aplicar la Prueba de Comparación Múltiple de Tukey con el propósito de establecer el mejor tratamiento. Con relación a los resultados de digestibilidad se determinaron los valores obtenidos para cada tratamiento, teniendo en cuenta que no se efectuó análisis estadístico debido a que las heces de las diferentes replicas que componían cada tratamiento fueron homogenizadas. La digestibilidad se calculó de acuerdo a las siguientes formulas: (8).

\section{Variables de digestibilidad}

Coeficiente de digestibilidad total. DT $=100-100 *\left[\% \mathrm{Cr}_{2} \mathrm{O}_{3} \mathrm{AL} / \% \mathrm{Cr}_{2} \mathrm{O}_{3} \mathrm{H}\right]$, 
Where:

CUE: coefficient of energy utilization

EBA: Brute Feed Energy

The productive variables were calculated as follows:

\section{Productive variables}

Increase in biomass.

$\mathrm{IB}=[\mathrm{BF}-\mathrm{BI}]$,

Where:

BF: final biomass

BI: initial biomass

\section{Simple growth rate.}

$\mathrm{SGR}=[(\operatorname{In} \mathrm{PF}-\operatorname{In} \mathrm{PI}) / \mathrm{t} * 100]$,

Where:

PF: final weight

PI: initial weight

t: sample period

Size increase.

$\mathrm{IT}=[\mathrm{TF}-\mathrm{TI}]$,

Where:

TF: final size

TI: initial size

Feed conversion.

$\mathrm{CA}=[\mathrm{AC} / \mathrm{IP}]$,

Where:

AC: consumed feed

IP: weight increase

\section{Survival.}

$\mathrm{S}=[(\mathrm{NF} / \mathrm{NI}) * 100]$,

Where:

NF: number of animals at the end

NI: number of animals at the beginning

Analysis of benefit-cost relationship.

$\mathrm{B} / \mathrm{C}=[(\mathrm{UB} / \mathrm{TE}) * 100]$,

Where:

UB: brute utility

TE: total expenditure

\section{RESULTS}

The experimental diets were balanced according to the quantities of different raw materials as shown in table 2 and were incorporated to ensure the isonitrogenous and isocaloric conditions of the diets for further evaluation.

The greatest values for digestibility, protein, fat and energy utilization coefficients were found in treatment T3 (30 ESH) with a value of 72.5 (Table 3). It is important to highlight that treatments that incorporated hydrolyzed viscera (ESH) at levels of 10 (T1), 20 (T2) and 30
Dónde:

$\% \mathrm{Cr}_{2} \mathrm{O}_{3}$ AL: cantidad de $\mathrm{Cr}_{2} \mathrm{O}_{3}$ en el alimento $\% \mathrm{Cr}_{2} \mathrm{O}_{3} \mathrm{H}$ : cantidad de $\mathrm{Cr}_{2} \mathrm{O}_{3}$ en las heces

\section{Coeficiente de digestibilidad.}

$\mathrm{CD}=100-\left[\left(\% \mathrm{Cr}_{2} \mathrm{O}_{3} \mathrm{AL} / \% \mathrm{Cr}_{2} \mathrm{O}_{3} \mathrm{H}\right) *\right.$

$(\% \mathrm{NH} / \% \mathrm{NAL}) * 100]$,

Donde:

$\% \mathrm{Cr}_{2} \mathrm{O}_{3} \mathrm{AL}$ : cantidad de $\mathrm{Cr}_{2} \mathrm{O}_{3}$ en el alimento

$\% \mathrm{Cr}_{2} \mathrm{O}_{3} \mathrm{H}$ : cantidad de $\mathrm{Cr}_{2} \mathrm{O}_{3}$ en las heces

$\% \mathrm{NH}$ : cantidad de nutrientes en las heces

\%NAL: cantidad de nutrientes en el alimento

\section{Coeficiente de utilización energética.}

CUE $=100-\left[\left(\% \mathrm{Cr}_{2} \mathrm{O}_{3} \mathrm{AL} / \% \mathrm{Cr}_{2} \mathrm{O}_{3} \mathrm{H}\right) *\right.$

$(\% \mathrm{EBH} / \% \mathrm{EBA}) * 100]$,

Donde:

$\% \mathrm{Cr}_{2} \mathrm{O}_{3}$ AL: cantidad de $\mathrm{Cr}_{2} \mathrm{O}_{3}$ en el alimento

$\% \mathrm{Cr}_{2} \mathrm{O}_{3} \mathrm{H}$ : cantidad de $\mathrm{Cr}_{2} \mathrm{O}_{3}$ en las heces

$\% \mathrm{EBH}$ : energía bruta en heces

$\%$ EBA: energía bruta en el alimento

\section{Energía digestible.}

$\left.E D=\left[C U E^{*} E B A\right) / 100\right]$,

Donde:

CUE: coeficiente de utilización energética

EBA: Energía Bruta de Alimento

Las variables productivas se calcularon asi:

\section{Variables productivas}

Incremento de biomasa.

$\mathrm{IB}=[\mathrm{BF}-\mathrm{BI}]$,

Donde:

BF: biomasa final

BI: biomasa inicial

Tasa de crecimiento simple.

$\mathrm{SGR}=[(\ln \mathrm{PF}-\ln \mathrm{PI}) / \mathrm{t} * 100]$,

Donde:

PF: peso final

PI: peso inicial

$\mathrm{t}$ : periodo muestreo

Incremento de talla.

$\mathrm{IT}=[\mathrm{TF}-\mathrm{TI}]$,

Donde:

TF: talla final

TI: talla inicial

\section{Conversión alimenticia.}

$\mathrm{CA}=[\mathrm{AC} / \mathrm{IP}]$,

Donde:

AC: alimento consumido

IP: incremento de peso

\section{Sobrevivencia.}

$\mathrm{S}=[(\mathrm{NF} / \mathrm{NI}) * 100]$, 
Table 2. Percentage of each raw material to be included per $100 \mathrm{~g}$ of feed for each treatment including dry hydrolyzed viscera.

\begin{tabular}{lcccc}
\hline \multicolumn{1}{c}{ Raw material } & $\begin{array}{c}\text { T0 } \\
(\mathbf{\%})\end{array}$ & $\begin{array}{c}\text { T1 } \\
(\mathbf{\%})\end{array}$ & $\begin{array}{c}\text { T2 } \\
(\mathbf{\%})\end{array}$ & $\begin{array}{c}\text { T3 } \\
(\mathbf{\%})\end{array}$ \\
\hline Meat flour & 25 & 26.7 & 25 & 20 \\
Soy flour & 34 & 32 & 30.8 & 36.5 \\
Fish flour & 18 & 13 & 8 & 4 \\
Hydrolyzed cachama viscera silage & 0 & 10 & 20 & 30 \\
Ground corn & 5.7 & 8.9 & 2.2 & 1 \\
Roasted bean flour & 4 & 2 & 6.7 & 2.2 \\
Wheat bran & 8 & 2 & 2 & 1 \\
Fish oil & 3 & 3 & 3 & 3 \\
Carboxymethyl celullose (CMC) & 1 & 1 & 1 & 1 \\
Chromium oxide & 0.9 & 0.9 & 0.9 & 0.9 \\
Vitamin and mineral pre mix & 0.3 & 0.3 & 0.3 & 0.3 \\
\hline
\end{tabular}

(T3)\% digestibility had digestibility percentages greater than $6,1.7$ and $9.4 \%$ of the total relative digestibility in relation to control treatment TO $(0$ ESH) that consisted of a balanced diet without dry hydrolyzed product.

The results of productive variables during 14 days of evaluation establish significant differences in apparent food consumption ( $p \leq 0.05)$, which indicates improved palatability in T0 and T2. Treatments $\mathrm{T} 1$ and $\mathrm{T} 3$ did not differ significantly according to the Tukey test $(p \leq 0.05)$, as shown in figure 1.

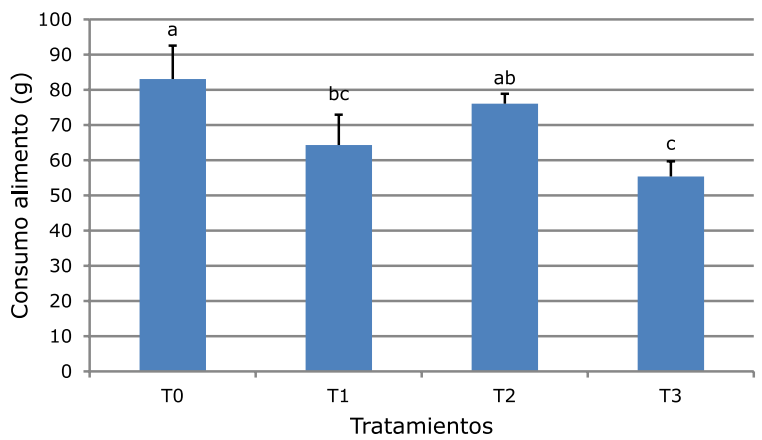

Figure 1. Apparent consumption of dry extract of viscera hydrolyzed product in the different treatments.

The simple average growth rate (SGR) for silver arawana alevin had increases above 0.09 and $0.88 \%$ for T1 (10 ESH) and T2 (20ESH) treatments respectively when compared to control treatment TO (OESH) (Table 4). The analysis of variance $(p \leq 0.05)$ for the increased average length of the different treatments detected statistically significant differences. The Tukey significance test indicated that T1 (10 $\mathrm{ESH}$ ) recorded the greatest increases, averaging $1.21 \pm 0.29 \mathrm{~cm}$, and the lowest value recorded for this variable was T3 (30 ESH) with $0.26 \pm 0.15$ $\mathrm{cm}$ (Figure 2).
Donde:

NF: número de animales al final

NI: número de animales al inicio

Análisis de relación beneficio - costo.

$\mathrm{B} / \mathrm{C}=[(\mathrm{UB} / \mathrm{TE}) * 100]$,

Donde:

UB: utilidad bruta

TE: total de egresos

Table 3. Digestibility coefficient (\%) of protein, ether extract, non-nitrogenized extract and energy utilization coefficient of diets prepared with dry hydrolyzed viscera.

\begin{tabular}{lcccc}
\hline Digestibility coefficient (\%) & $\begin{array}{c}\text { T0 } \\
\text { (0ESH) }\end{array}$ & $\begin{array}{c}\text { T1 } \\
\text { (10ESH) }\end{array}$ & $\begin{array}{c}\text { T2 } \\
\text { (20ESH) }\end{array}$ & $\begin{array}{c}\text { T3 } \\
\text { (30ESH) }\end{array}$ \\
\hline Total digestibility coefficient & 63.1 & 69.1 & 64.8 & 72.5 \\
(CDT) & 76.9 & 81 & 78.1 & 81.2 \\
Protein(P) & 85 & 89 & 90.2 & 90.4 \\
Ether extract (EE) & 53.8 & 62 & 51.6 & 63.6 \\
Non-nitrogenized extract & 57.2 & 72.6 & 69.2 & 75.2 \\
(ENN) & & & & \\
Energy use coefficient (CUE) & 67.2
\end{tabular}

\section{RESULTADOS}

Las dietas experimentales fueron balanceadas según las cantidades de las diferentes materias primas como se presenta en la tabla 2, las cuales se incorporaron para asegurar las condiciones isoenergéticas e isonitrogenadas de las dietas para su posterior evaluación.

Los mayores valores de digestibilidad, de proteína, lípidos y coeficientes de utilización energética se encontraron en el tratamiento T3 (30 ESH) con un valor de 72.5 (Tabla 3). Es importante destacar que los tratamientos que incorporaban extracto seco de hidrolizado de vísceras (ESH) en niveles del 10 (T1), 20 (T2) y 30 (T3) \% registraron digestibilidades porcentuales mayores de $6,1.7$ y $9.4 \%$, de la digestibilidad total con relación al tratamiento testigo T0 (0 ESH) constituido por un balanceado sin extracto seco de hidrolizado.

Los resultados de las variables productivas durante 14 días de evaluación, establecen diferencias significativas en el consumo aparente del alimento $(p \leq 0.05)$, lo que permite indicar mejor palatabilidad en los balanceados T0 y T2. Los tratamientos T1 y T3 no presentaron diferencias significativas de acuerdo a la prueba de Tukey ( $p \leq 0.05)$, como lo muestra la figura 1. La tasa promedio de crecimiento simple (SGR) para alevinos de arawana plateada registró incrementos superiores de 0.09 y $0.88 \%$ para los tratamientos T1 (10 ESH) y T2 (20ESH) respectivamente en comparación al tratamiento testigo T0 (0ESH) (Tabla 4). El análisis de 


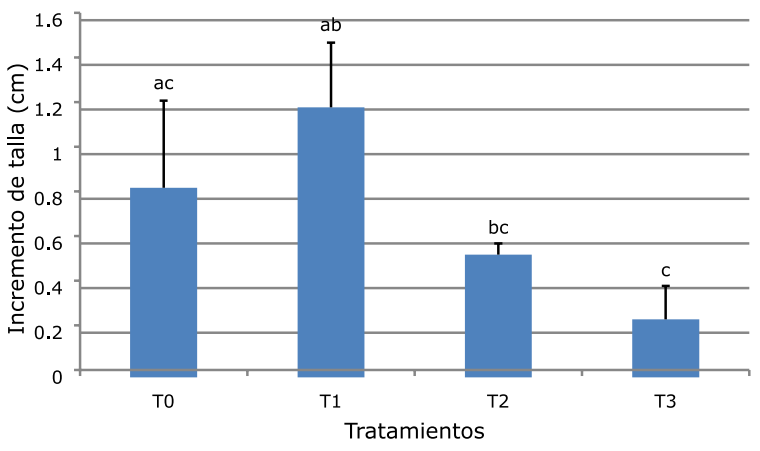

Figure 2. Increased standard length in the different treatments with dry viscera hydrolyzed product.

Regarding the apparent feed conversion, it was found that there are no statistically significant differences between the averages of the different treatments $(p>0.05)$; (Table 4$)$.

Table 4. Results of productive variables in the different treatments with dry hydrolyzed viscera.

\begin{tabular}{cccccc}
\hline TTO & SGR(\%) & ITT(cm) & ITD (cm) & CA & $\begin{array}{c}\mathbf{R} \\
(\%)\end{array}$ \\
\hline T0 & $1.67 \pm 1.62^{\mathrm{a}}$ & $0.85 \pm 0.39^{\mathrm{ac}}$ & $0.060 \pm 0.39^{\mathrm{ac}}$ & $1.95 \pm 0.38^{\mathrm{a}}$ & 69.48 \\
T1 & $1.76 \pm 1.20^{\mathrm{a}}$ & $1.21 \pm 0.29^{\mathrm{ab}}$ & $0.086 \pm 0.29^{\mathrm{ab}}$ & $1.50 \pm 0.04^{\mathrm{a}}$ & 82.64 \\
T2 & $2.55 \pm 1.30^{\mathrm{a}}$ & $0.55 \pm 0.05^{\mathrm{bc}}$ & $0.039 \pm 0.05^{\mathrm{bc}}$ & $1.57 \pm 0.35^{\mathrm{a}}$ & 56.56 \\
T3 & $1.64 \pm 1.30^{\mathrm{a}}$ & $0.26 \pm 0.15^{\mathrm{c}}$ & $0.018 \pm 0.15^{\mathrm{c}}$ & $1.69 \pm 0.05^{\mathrm{a}}$ & 56.56 \\
\hline
\end{tabular}

$\pi \mathrm{TO}=$ Treatment, $\mathrm{SGR}=$ Simple growth rate, $\mathrm{ITT}=$ Length increase over 14 days , ITD = Daily length increase, $C A=$ feed conversion, $R=$ Profitability

Survival during the experiment was $100 \%$ for the four treatments. They were greatly tolerant of manipulation and stress caused by cleaning routines, changes, fecal collection and uneaten food removal as well as census for biometric records. According to the analysis of variance ( $p>$ 0.05 ), the physical and chemical parameters of water were similar in all treatments during the study period, and are within the ranges required for cultivating silver arawana (Table 5).

The cost-benefit estimate shows that all treatments are economically viable; T1 (10 ESH) showed a ratio of 1.82 , TO $(0 \mathrm{ESH}) 1.69$, and treatments T2 (20 ESH) and T3 (30 ESH) 1.56 (Table 3, Figure 3).

Table 5. Average physicochemical parameters in the different treatments.

\begin{tabular}{cccc}
\hline Treatment & Oxygen $(\mathbf{m g} / \mathbf{I})$ & $\mathbf{p H}$ & Temperature $\left.^{\circ} \mathbf{C}\right)$ \\
T0 & $4.97 \pm 0.24^{\mathrm{a}}$ & $6.80 \pm 0.23^{\mathrm{a}}$ & $30.49 \pm 1.26^{\mathrm{a}}$ \\
T1 & $4.90 \pm 0.22^{\mathrm{a}}$ & $6.76 \pm 0.23^{\mathrm{a}}$ & $30.22 \pm 1.11^{\mathrm{a}}$ \\
T2 & $4.94 \pm 0.23^{\mathrm{a}}$ & $6.73 \pm 0.27^{\mathrm{a}}$ & $30.27 \pm 0.99^{\mathrm{a}}$ \\
T3 & $4.93 \pm 0.21^{\mathrm{a}}$ & $6.77 \pm 0.25^{\mathrm{a}}$ & $30.44 \pm 1.02^{\mathrm{a}}$ \\
\hline
\end{tabular}

varianza $(p \leq 0.05)$, para el incremento de longitud promedio de los diferentes tratamientos, detectó diferencias estadísticas significativas. La prueba de significancia de Tukey indicó que el T1 (10 ESH), registró los mejores incrementos con un promedio de $1.21 \pm 0.29 \mathrm{~cm}$, el valor más bajo en esta variable lo registró el T3 (30 ESH) con $0.26 \pm 0.15 \mathrm{~cm}$ (Figura 2).

Con respecto a la conversión alimenticia aparente, se encontró que no existen diferencias estadísticas significativas entre las medias de los diferentes tratamientos ( $p>0.05)$; (Tabla 4). La sobrevivencia durante el período experimental fue del $100 \%$ para los cuatro tratamientos; observándose una alta resistencia a la manipulación y el estrés, causado por las rutinas de aseo, recambios, recolección de heces y retiro del alimento no consumido, además, de los censos para los registros biométricos. Los parámetros físico-químicos de agua fueron similares en todos los tratamientos, según el análisis de varianza ( $p>0.05$ ) durante su período de estudio, y están dentro de los rangos requeridos para el cultivo de la arawana plateada (Tabla 5).

La relación costo-beneficio estimado, demuestra que todos los tratamientos son viables económicamente, de tal manera que el T1 (10 ESH) registró una relación de 1.82 , el tratamiento T0 (0 ESH) con 1.69 , y de 1.56 para los tratamientos T2 (20 ESH) y T3 (30 ESH), (Tabla 3, Figura 3).

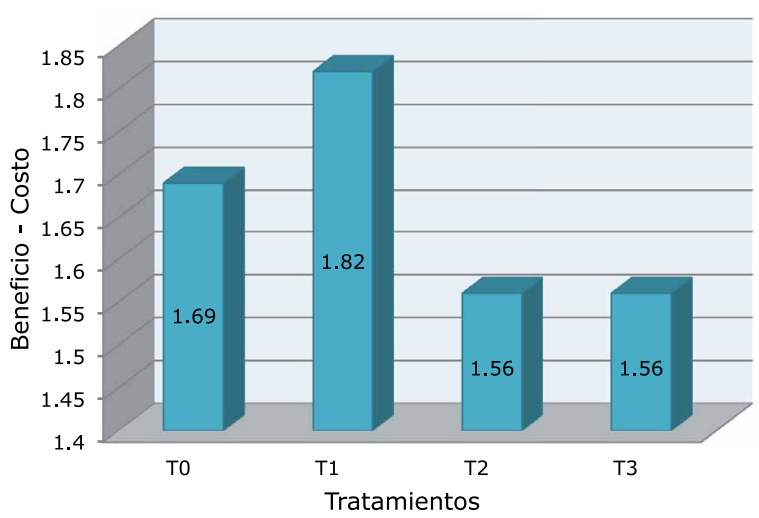

Figure 3. Cost benefit relationship per treatment.

\section{DISCUSIÓN}

La investigación confirma que la utilización de materias primas de alta digestibilidad en las dietas para peces, mejora la conversión alimenticia, aumento de las tasas de crecimiento, y reduce el impacto ambiental negativo, generado por el aporte de residuos nitrogenados y fosforados debido a la 


\section{DISCUSSION}

Research confirms that the use of highly digestible raw materials in fish diets improves feed conversion, increases growth rates and reduces negative environmental impacts generated by the nitrogen and phosphorus waste from disposing of viscera in water bodies (9). Also, it was found that protein digestibility, ether extract and energy for the different treatments showed values higher than $60 \%$, ensuring remodeling processes and cell growth and demonstrating the nutritional quality of the diets represented in the content of essential amino acids, the interaction of nutrients, and the soluble and water-soluble vitamins and minerals found in hydrolyzed cachama viscera (3).

Percentage values of digestibility of ether extracts in T1 (10 ESH), T2 (20 ESH), and T3 (30ESH) exceed $85 \%$ due to the elevated composition of fatty acid in hydrolyzed fish viscera, particularly unsaturated Omega 3 and Omega 6 fatty acids that have multiple physiological functions related to growth and the immune system and record greater digestibility when compared with fats present in traditional products that are less digestible (10).

The increase in weight and height reported in this study are consistent with other studies that show that silver arawana alevin raised in captivity under similar conditions have increased in average weight between $0.15 \mathrm{~g} /$ day and $0.20 \mathrm{~g} /$ day (1). The best digestibility values and analysis of productive variables were found in treatments with dry hydrolyzed fish viscera due to the biological quality, amino acids, interaction of nutrients and the presence of nonspecific growth factors in this product (1). Also, similarities with other studies reported increases in daily size from $0.06 \mathrm{~cm}$ to $0.08 \mathrm{~cm}$, which shows that diets that include dry hydrolyzed cachama viscera can produce growth up to $1.21 \mathrm{~cm}$ in two weeks in total length during the initial developmental phase, which is highly important for fish species that are of interest to the fish industry (12).

Feed conversion and feed intake in the different experimental diets did not have statistical differences, showing that the inclusion of different percentages of dry hydrolyzed viscera to feed arawana does not affect yield, keeping in mind that weight increases were also statistically similar in all treatments. In contrast, size was significant in Q1 relative to the other treatments, important for this important species to the fish industry (13). eliminación de las vísceras en los cuerpos de agua (9). Asimismo, se comprueba que la digestibilidad de la proteína, extracto etéreo y energía para los diferentes tratamientos registraron valores superiores al $60 \%$, asegurando los procesos de remodelación y crecimiento celular; demostrando la calidad nutricional de las dietas, representada por el contenido de aminoácidos indispensables, la interacción de nutrientes, el aporte de vitaminas liposolubles e hidrosolubles y minerales presentes en el extracto seco de hidrolizado de vísceras de cachama (3).

Los valores porcentuales de digestibilidad del extracto etéreo en los tratamientos T1 (10 ESH), T2 (20 ESH), y T3 (30ESH) superan el $85 \%$, debido a la composición elevada de ácidos grasos en los hidrolizados de vísceras de pescado, principalmente de ácidos grasos insaturados de las series omega 3 y omega 6 , los cuales tienen múltiples funciones fisiológicas relacionadas con el crecimiento y el sistema inmunológico y registran mejor digestibilidad comparados con las grasas presentes en las materias primas tradicionales que son de menor digestibilidad (10).

Los incrementos de peso y talla reportados en esta investigación, están acordes con otros estudios en donde se demuestra que alevinos de arawana plateada levantados en cautiverio en condiciones similares, obtuvieron un incremento de peso promedio entre $0.15 \mathrm{~g} /$ día y $0.20 \mathrm{~g} /$ día (1). Los mejores valores de digestibilidad y análisis de las variables productivas se encontraron en los tratamientos con extracto seco de hidrolizado de vísceras de pescado, debido a la calidad biológica, composición de aminoácidos, interacción de nutrientes y presencia de factores inespecíficos de crecimiento en esta materia prima (11). De igual manera se presenta similitudes con otros ensayos que reportan incrementos de talla diarios entre $0.06 \mathrm{~cm}$ a $0.08 \mathrm{~cm}$., lo que explica que las dietas con inclusiones de extracto seco de hidrolizado de vísceras de cachama pueden alcanzar hasta 1.21 $\mathrm{cm}$ quincenales en su longitud total en el desarrollo de su fase inicial, lo cual es de gran importancia para una especie íctica de interés acuariofílico (12).

La conversión alimenticia y el consumo de alimento de las distintas dietas experimentales no registraron diferencias estadísticas, lo que demuestra que la inclusión de diferentes porcentajes del extracto seco de hidrolizado de vísceras en la alimentación de arawana, no afecta el rendimiento productivo de la especie, teniendo en cuenta que los incrementos de peso fueron también similares estadísticamente en todos los tratamientos. En contraste la talla fue significativa en el T1 con relación a los demás tratamientos, condición importante para este pez de valor acuariofilico (13). 
The economic analysis has shown the feasibility of using dry extracts of hydrolyzed fish entrails or waste, using it as a partial substitute for fishmeal, an expensive raw material that is increasingly scarce on the market. Therefore, we recommend using this fish waste according to the methodology described in this study as an ecological and economic alternative to reduce production costs and prevent contamination of water sources.

The results of this study allow us to conclude that diets with dry hydrolyzed viscera between 10 and $30 \%(\mathrm{p} / \mathrm{v})$ are adequately digestible and including them at $10 \%$ ensures good productive performance in cultivating arawana. We recommend including this raw material in fish feed as a protein source and as a substitute for commercial fish silage.

\section{Acknowledgements}

The Aquaculture Association of Caquetá (ACUICA) for funding this research, to the Universidad Nacional de Colombia, located in Bogota, for academic and logistical support of the Aquaculture Production Engineering program of the Universidad de Nariño and to all people who in one way or another contributed to this research.
El análisis económico muestra la viabilidad que tiene el uso de extractos secos de hidrolizados biológicos a base de vísceras o desechos de pescados, utilizándolo como un sustituto parcial de la harina de pescado, materia prima costosa y cada vez más escasa en el mercado. Por tanto, se recomienda promover la utilización de estos desechos pesqueros utilizando la metodología descrita en esta investigación como una alternativa ecológica y económica para reducir los costos de producción y evitar la contaminación de los cuerpos de agua.

Los resultados del presente estudio permiten concluir que las dietas con extracto seco de hidrolizado de vísceras entre 10 y $30 \%(p / v)$ presentan una digestibilidad adecuada e incluirlos en $10 \%$ permite buen desempeño productivo para el levante de arawana, se recomienda la inclusión de esta materia prima en las dietas para peces como fuente proteica y sustituto de la harina de pescado comercial.

\section{Agradecimientos}

A la Asociación de Acuicultores del Caquetá (ACUICA) por la financiación de esta investigación, a la Universidad Nacional de Colombia con sede en Bogotá, por su apoyo académico y logístico, al programa de Ingeniería en producción Acuícola de la Universidad de Nariño y a todas las personas que de alguna u otra manera colaboraron en el desarrollo de la investigación.

\section{REFERENCES}

1. Hernández Olaya C, Gómez Ramírez E, Hurtado Giraldo, H. Estudio Preliminar del Levante de Juveniles de Arawana Plateada (Osteoglossum bicirrhosum) en Sistemas Cerrados de Recirculación. Revista Facultad de Ciencias Básicas 2010; 6(1):96-113.

2. Mancera N, Álvarez R. Comercio de Peces Ornamentales en Colombia. Acta Biológica Colombiana 2008; 13(1):23-51

3. López Macías J. Nutrición y Alimentación Piscícola. Colombia: Editorial Universidad de Nariño; 2014.

4. Instituto de Hidrología, Meteorología y Estudios Ambientales (IDEAM). Centro de documentación, Visor Geográfico. Colombia: [en línea] 2012. [fecha de acceso 20 de abril 2012] URL disponible en: http://geoapps. ideam.gov.co:8080/geovisor/index.jsf
5. Spanopoulos Hernández M, Ponce Palafox J, Barba Quintero G, Ruelas Inzunza J, Tiznado Contreras M, Hernández Gonzales $C$ et al. Producción de ensilados biológicos a partir de desechos de pescado, del ahumado de atún aleta amarilla (Thunnus albacares) y del fileteado de tilapia (Oreochromis $s p$ ), para la alimentación de especies acuícolas. Revista Mexicana de Ingeniería Química 2010; 9(2):167-178.

6. Llanes J, Toledo J, Fernandez I, Lazo de la Vega J. Estudio del ensilado biológico de pescado como inóculo de bacterias lácticas en la conservación de desechos pesqueros. Redvet 2007; 8(9):1695-7504.

7. Vásquez Torres W. Principios de Nutrición Aplicada al Cultivo de Peces. Colombia: Universidad de los Llanos; 2004. 
8. Silva J, Pereira M, Cavero B, Oliviera M. Digestibilidade aparente dos nutrientes e energia de ração suplementada com enzimas digestivas exógenas para juvenis de tambaqui (Colosssoma macropomum Cuvier, 1818). Acta Amaz 2007; 37(1):157-164

9. Rueda W, Vásquez W, Gutiérrez M. Digestibilidad de fosforo y proteína de raciones suplementadas con fitasa en tilapia, Oreochromis sp. Orinoquia 2012; 16(1):20-29.

10. Llanes Iglesias J, Bórquez A, Toledo Pérez J, Lazo de la Vega J. Digestibilidad aparente de los ensilajes de residuos pesqueros en tilapias rojas (Oreochromis mossambicus y O. niloticus). Zootecnia Trop 2010; 28(4):499-505.
11. Gutiérrez Walter, Zaldívar Javier, Contreras Guadalupe. Coeficientes de digestibilidad aparente de harina de pescado peruana y maíz amarillo duro para Colossoma macropomum (Actinopterygii, characidae). Orinoquia 2012; 16(2):179-186.

12. Cuaical C, Vallejo E, Franco H, Sanguino W. Efecto de la densidad de siembra y la adición de ácido ascórbico en el cultivo de Osteoglossum bicirrhosum. Rev MVZ Córdoba 2013; 18(3):3799-3806.

13. Llanes Iglesias J, Toledo Pérez J, Lazo de la Vega J. Tecnología de producción de alimento semi-húmedo a base de ensilados de residuos pesqueros en la alimentación de tilapia roja (Oreochromis mossambicus $x$ O. niloticus). Redvet 2007; 8(9):1695-7504. 